\title{
Histological Changes of Maternal Risperidone and Folic acid on the Cerebellar Cortex of the Offspring of the Albino Rat
}

Original
Article

Safaa M. Hanafy

Department of Anatomy, Faculty of Medicine (Girls), Al-Azhar University

\begin{abstract}
Background: Risperidone is atypical, second-generation antipsychotic and folic acid is a water-soluble B vitamin. Objective: Assessment of the effect of risperidone on the development of the cerebellar cortex of albino rats, and evaluation of the protective potential of folic acid.

Material and Methods: The study involved treatment of 60 pregnant rats and examination of 180 of their offspring. The pregnant rats were divided equally into five groups (I-V), each of which was subdivided equally into two subgroups (A and B). Rats in the A subgroups were gavaged with a daily dose of $1 \mathrm{ml}$ distilled water (subgroup IA), $0.58 \mathrm{ml}$ distilled water (subgroup IIA), $0.072 \mathrm{mg}$ Folic acid (subgroup IIIA), $0.108 \mathrm{mg}$ risperidone (subgroup IVA) or $0.108 \mathrm{mg}$ risperidone with $0.072 \mathrm{mg}$ folic acid (subgroup VA), throughout pregnancy. Rats in the B subgroups received the same regimen throughout pregnancy and for 21 days after delivery. The cerebella of all studied offspring were subjected for light microscopic examination. In addition, the cerebella of 21 day old offspring were used for electron microscopic examination and morphometric study.

Results: Risperidone induced signs of delayed development and degenerative changes in the cerebellar cortex. The degenerative changes were; cytoplasmic vacuoles, dilated rough endoplasmic reticulum, swollen mitochondria with destructed cristae, degenerated mitochondria and nuclear changes. Co-administration of folic acid with risperidone ameliorated the delayed development and the degenerative changes.

Conclusion: Treatment of the pregnant rats with risperidone induced delayed development and degenerative changes in the cerebellar cortex of their offspring. The co-administration of folic acid with risperidone led to an amelioration of these deleterious effects. So, in pregnant and lactating women treated with risperidone, co-supplementation with folic acid is advisable.
\end{abstract}

Received: 15 June 2019, Accepted: 06 August 2019

Key Words: Cerebellum; folic acid; offspring; pregnant rats; risperidone.

Corresponding Author: Safaa Masoud Hanafy, PhD, Department of Anatomy and Embryology, Faculty of Medicine (Girls), Al-Azhar University, Cairo, Egypt, Tel: +20 1019623604, E-mail: sadekamin66@yahoo.com

ISSN: 1110-0559, Vol. 42, No. 3

\section{INTRODUCTION}

Risperidone was a benzisoxazole derivative characterized by moderately high affinity for D2, histamine 1 (H1), alpha1 and alpha 2 adrenergic receptors, and a markedly high affinity for 5 HT2A receptors ${ }^{[1]}$. It go through first pass hepatic metabolism to 9-hydroxy risperidone, a metabolite with equal antipsychotic action. The combined half-life of risperidone averaged twenty hours. So, it is efficient in a once daily dosing ${ }^{[2]}$. Risperidone was an atypical antipsychotic, a secondgeneration neuroleptic drug that has been involved in the treatment of different psychotic disorders such as schizophrenia and bipolar disorder ${ }^{[3,4,5]}$. Second-generation antipsychotics had minor incidence of extrapyramidal side effects as compared to first-generation antipsychotics ${ }^{[6]}$. Among second generation atypical antipsychotic drugs, risperidone (RIS) ranked third after olanzapine (OLZ) and quetiapine (QUE) used during pregnancy ${ }^{[7,8]}$. Although teratogenic safety of risperidone has been settled, its possible role in developmental neurotoxicity and associated neurobehavioral impairments in adolescents had not been documented so far $^{[9]}$.

Folic acid was pteroylglutamic acid contained a pteridine ring linked by a methylene bridge to paraaminobenzoic acid, which was joined by an amide linkage to glutamic acid ${ }^{[10]}$. It could not be synthesized de novo by the body, and must be obtained either supplementation or from diet ${ }^{[11]}$. It was a water-soluble B vitamin, occurred naturally in fruits, leafy green vegetables, and other foods $^{[12]}$.

Folic acid itself was inactive. In the body, it was transformed to folinic acid, which was its active form. Folinic acid is 5-formyl tetrahydrofolic acid. It participated in the production of purines and pyrimidines leading to synthesis of deoxyribonucleic acid and thus regulated cell division $^{[13]}$. Systematic reviews on folic acid had revealed that folic acid diminished effectively the risk of neural tube defects in both low- and high-income countries ${ }^{[14,15]}$.

As the potential role of risperidone in developmental 
neurotoxicity and related neurobehavioral impairments had not been documented so far, the aim of this study was to assess the effect of risperidone (intake to pregnant albino rats) on the cerebellar cortex (of their offspring) and evaluate the protective potential of folic acid.

\section{MATERIAL AND METHODS}

\section{Drugs}

Risperidone was obtained from Pharaonia Pharmaceuticals, Alexandria, Egypt. It was available in the form of tablets, each contained $2 \mathrm{mg}$. The recommended human usual adult antipsychotic oral dose is $2-8 \mathrm{mg} /$ day ${ }^{[10]}$. The chosen dose was $6 \mathrm{mg} /$ day $^{[16,17]}$. The optimal dose of prescribing risperidone is $6 \mathrm{mg}$ per day as this dose can manage extra pyramidal effects ${ }^{[18,16]}$. According to Paget and Barnes ${ }^{[19]}$, the dose of risperidone per adult rat (weighing 200 gram) was $0.108 \mathrm{mg} / \mathrm{rat} / \mathrm{day}$. Each tablet was dissolved in $18.6 \mathrm{ml}$ of distilled water and each rat was given $1 \mathrm{ml}$ distilled water containing $0.108 \mathrm{mg}$ risperidone.

Folic acid was obtained from Nile Pharmaceutica Company, Egypt. It was available in the form of tablets, each contained $5 \mathrm{mg}$. The recommended human dose in pregnant patient receiving antipsychotic drugs is $4 \mathrm{mg} /$ day, taken orally ${ }^{[20]}$ to avoid neural tube defect. According to Paget and Barnes ${ }^{[19]}$, the dose of folic acid per adult rat (weighing 200 gram) was $0.072 \mathrm{mg} / \mathrm{rat} /$ day. Each tablet was dissolved in $40.3 \mathrm{ml}$ of distilled water and each rat was given $0.58 \mathrm{ml}$ distilled water containing $0.072 \mathrm{mg}$ folic acid.

\section{Animals}

Eighty adult albino rats of local strain weighing about 200 gm. were used (60 females and 20 males) in this experimental study. They were provided by veterinary care through the Animal House of Faculty of Medicine (Girls), Al- Azhar University according to the guidelines for animal research that were approved by the Animal Ethics Committee. The rats were observed and maintained on balanced diet and water (Standard diet pellets consisted of, $3.5 \%$ fats, $5 \%$ fibers, $20 \%$ proteins and $6.5 \%$ ash). Three virgin females were located overnight with one male in a separate cage. Females that showed a vaginal plug in the next morning were determined to be in her first day of pregnancy ${ }^{[21]}$. The pregnant rats were kept in separate cages with their offspring till the end of the experiment. The dimensions of the cages for pregnant rats were $30 \mathrm{~cm}$ length, $40 \mathrm{~cm}$ width and $15 \mathrm{~cm}$ height.

Experimental design: Pregnant albino rats $(n=60)$ were divided equally to five groups (I, II, III, IV, V). Each group had two subgroups (A, B) with six pregnant rats per subgroup. In the A subgroups, each pregnant rat received a single dose delivered each day by gavage throughout pregnancy. In the B subgroups, each pregnant rat received a single dose delivered each day throughout pregnancy and for 21 days after delivery. In group I (control 1), each pregnant albino rat was gavaged $1 \mathrm{ml}$ distilled water. In group II (control 2), each pregnant albino rat was gavaged $0.58 \mathrm{ml}$ distilled water. In group III (folic acid treated), each pregnant albino rat was gavaged $0.58 \mathrm{ml}$ distilled water contained $0.072 \mathrm{mg}$ folic acid. In group IV (Risperidone treated), each pregnant albino rat was gavaged $1 \mathrm{ml}$ of distilled water contained $0.108 \mathrm{mg}$ risperidone. In group V (Risperidone and folic acid treated), each pregnant albino rat was gavaged $1 \mathrm{ml}$ distilled water contained $0.108 \mathrm{mg}$ risperidone and $0.58 \mathrm{ml}$ distilled water contained $0.072 \mathrm{mg}$ folic acid. For each subgroup, 18 offspring were analyzed.

\section{Collection of the specimens and preparation for examination}

The cerebellum of the offspring was harvested, either on the first day after delivery for the A subgroups, or 21 days after delivery for the B subgroups. Each rat was anaesthetized lightly by isoflurane inhalation and decapitated with straight, thin and sharp scissors. The cap and side walls of the cranium were carefully removed. The dura mater was carefully incised all around, then raised up. The falx cerebri was removed and tentorium cerebelli was cut out. The base of the brain was raised up, beginning from the frontal poles of the cerebral hemispheres. The cranial nerves were cut close to the base of the skull, then the cerebelli were gently removed.

\section{Histopathological analysis}

Cerebellum histopathological examination by light microscopy was performed on sections from all selected offspring (A and B subgroups). Sections from the cerebellum of offspring in the B subgroups were also analyzed by electron microscopy.

For light microscopy, cerebelli were immersed in Bouin's solution for three days ${ }^{[22]}$, then dehydrated in ascending grades of ethyl alcohol (70\%- 90\%-100\%) and cleared in benzene. The specimens were impregnated three times with paraffin and then embedded in paraffin wax. The paraffin blocks were cut by rotary microtome at $5 \mu \mathrm{m}$ thickness into serial sagittal sections. Every five sagittal sections (successive) were attached to albumenized glass slide. Heamatoxylin and eosin (H\&E) stain was used to study the general architectures ${ }^{[23]}$. The images were taken by a digital camera connected to a microscope (Leica) DM750 in Faculty of Medicine (Girls), Al-Azhar University, Cairo, Egypt.

For transmission electron microscopy, small pieces of the superficial layer of cerebellum were fixed immediately in $5 \%$ cold glutaraldehyde then washed in phosphate buffer $(0.1 \mathrm{ml}$ at $\mathrm{pH} 7.2)$. The specimens were then post-fixed with osmium tetroxide (1\%), then dehydrated, cleared and embedded in epoxy resin ${ }^{[23]}$. The semi-thin sections were cut at $1 \mu \mathrm{m}$ thick on LKB ultratome, stained with toluidine blue, and examined through light microscope ${ }^{[23]}$. At the Regional Mycology and Biotechnology Center, Al-Azhar University, Cairo, ultrathin sections $(60 \mathrm{~nm})$ were cut then examined through a transmission electron microscope (JEOL 1010 EX II; JEOL, Tokyo, Japan).

Morphometric analysis: H\&E stained sections of the cerebellar cortex of B subgroups were examined by 
means of a light microscope and using an image analyzer computer system. The image analyzer computer system Leica Qwin 500 (England), at the Regional Mycology and Biotechnology center, Al-Azhar University, Cairo, Egypt, was used to evaluate the thickness of the molecular layer and the number of the Purkinje cells. The 18 slides of 18 offspring were taken at the sagittal cerebellar cortex sections of each of B subgroups. To measure the thickness of the molecular layer and to count the number of Purkinje cells, the central five folia were selected in each slide. Measuring the thickness of the molecular layer was done by taking 6 different thicknesses for each folium at magnification x 200 using Image J software version 1.48. The number of Purkinje cells was counted in the central five folia in special fixed squares. The means of the thickness of the molecular layer and the means of the numbers of the Purkinje cells of each folium were calculated. Their data were subjected to statistical analysis.

Statistical analysis: The number of Purkinje cells and the thickness of the molecular layer were recorded and statistically analyzed. Statistical analysis was conducted, using the arithmetic mean, standard deviation, Analysis of variance [ANOVA] and Tukey's Post Hoc multiple comparisons tests. The results were considered significant when the $p$ value $<0.05^{[24]}$.

\section{RESULTS}

\section{One-day-old offspring}

In sagittal cerebellar cortex stained sections (H \& E) from offspring in subgroups IA, IIA, and IIIA, light microscopic examination revealed no obvious differences between the subgroups, so their data were pooled together. The cerebellar cortex consisted of four layers; the external granular layer, the molecular layer, the Purkinje cell layer and the internal granular layer (Figure 1A). The external granular layer was formed of 6 to 8 rows of granule cells. The superficial cells were almost closely packed together, while the deep cells were separated from each other. The granule cells were rounded or oval, variable in size, with deeply stained nuclei and prominent nucleoli (Figure 1A). The molecular layer appeared as a narrow pale zone beneath the external granular layer with few cells. The molecular cells were rounded or oval, with lightly stained basophilic nuclei (Figure 1A). The Purkinje layer consisted of 2-3 irregular rows of Purkinje cells. They were large, rounded or oval, with a large rounded vesicular basophilic nuclei and prominent nucleoli (Figure 1A). The internal granular layer consisted of granule cells, which were widely separated from each other. The granule cells were rounded or oval, with deeply stained basophilic nuclei (Figure 1A).

In sagittal cerebellar cortex stained sections (H \& E) from offspring in subgroup IVA, light microscopic examination revealed that the external granular layer was ill-developed as compared to the control one (Figure 1A) and (Figure 1B). It consisted of 4-6 rows of granule cells. The superficial and deep cells were separated from each other. The granule cells were rounded or oval, variable in size with deeply stained nuclei and prominent nucleoli. Most nuclei were surrounded by vacuolated cytoplasm (Figure 1B).The molecular layer presented as a narrow pale zone beneath the external granular layer. Their thickness appeared slightly thinner as compared to the control group (Figure 1A) and (Figure 1B). Some molecular cell nuclei were surrounded by area of vacuolated cytoplasm. The Purkinje cell layer consisted of 2-3 irregular rows of widely dispersed Purkinje cells. Many Purkinje cell nuclei were surrounded by area of vacuolated cytoplasm (Figure 1B).The granule cells of the internal granular layer appeared widely separated from each other. They were rounded or oval, variable in size with deeply stained nuclei (Figure 1B). Some of their nuclei were surrounded by vacuolated cytoplasm.

In sagittal cerebellar cortex stained sections (H \& E) from offspring in subgroup VA, light microscopic examination revealed that the external granular layer consisted of 6-7 rows of granule cells as compared to the subgroup IVA (Figure 1C) and (Figure 1B). The superficial cells were almost closely packed together, while the deep cells were separated from each other. The granule cells were rounded or oval, with deeply stained nuclei and prominent nucleoli. Some nuclei were surrounded by vacuolated cytoplasm (Figure 1C). The molecular layer presented as a narrow pale zone beneath the external granular layer. Their thickness appeared nearly similar to the control group (Figure 1C) and (Figure 1A). Few molecular cell nuclei were surrounded by area of vacuolated cytoplasm. The Purkinje cell layer consisted of 2-3 irregular rows of widely dispersed Purkinje cells. Few Purkinje cell nuclei were surrounded by area of vacuolated cytoplasm (Figure 1C). The granule cells of the internal granular layer appeared widely separated from each other. They were rounded or oval, variable in size with deeply stained nuclei. Few of their nuclei were surrounded by vacuolated cytoplasm (Figure 1C).

\section{Twenty one-day-old offspring}

\section{Light microscopy}

In sagittal cerebellar cortex stained sections (H \& E and toluidine blue) from offspring in subgroups IB, IIB and IIIB, light microscopic examination revealed no obvious differences between the subgroups, so their data were pooled together. Light microscopic examination showed that the cerebellar cortex was formed of 4 layers; the external granular layer, the molecular layer, the Purkinje cell layer and the internal granular layer (Figure 2A). The external granular layer appeared as one row beneath the pia matter in some areas or completely disappeared in other areas. The external granular cells were variable in size, rounded or oval, with deeply stained nuclei and prominent nucleoli (Figures 2A\&3A). The molecular layer became more developed as compared to the cortex of one day old offspring, its thickness was increased and its cells could be differentiated into stellate and basket cells. The stellate cells 
were present in the outer and middle third of the molecular layer and they were oval or rounded, with lightly stained nuclei and prominent nucleoli (Figures 2A, 2D\&3A). The basket cells were present in the middle and deep third of the molecular layer and in between the Purkinje cells. They were oval or rounded, with a lightly stained nuclei and prominent nucleoli (Figures 2A, 2G\&3D). The Purkinje cell layer appeared more developed and its cells became arranged in a single row. Most of the Purkinje cells were flask shaped, with a large vesicular nuclei and prominent nucleoli. The dendritic stems of the Purkinje cells were directed towards the molecular layer (Figures 2A, 2G\&3D). The internal granular layer was consisted of many granule cells which were aggregated in clusters and separated by small acidophilic areas. The cells were rounded or oval, variable in size, with deeply stained basophilic nuclei and prominent nucleoli (Figures 2A, 2G\&3D).

In sagittal cerebellar cortex stained sections $(\mathrm{H} \&$ $\mathrm{E}$ and toluidine blue) from offspring in subgroup IVB, light microscopic examination showed that it was formed of 4 layers; the external granular layer, the molecular layer, the Purkinje cell layer and the internal granular layer (Figure 2B). The external granular layer appeared ill-developed as it consisted of 3-4 rows of granule cells. Some of the granule cell nuclei were irregular, shrunken and deeply stained. Many of their nuclei were surrounded by vacuolated areas (Figures 2B, 2E\&3B). The molecular layer was apparently decreased as compared to the control one. Some of the stellate and basket cells had vacuolated cytoplasm (Figures 2B, 2H, 3B\&3E). The Purkinje cells were arranged in a single row superficial to the internal granular layer. Some of them appeared irregular and had ill-defined deeply stained irregular nuclei and others were surrounded by vacuolated areas. The cytoplasmic processes were misdirected (Figures 2B, 2E\&2H) as compared with the control (Figures 2A, 2G\&3D). The internal granular layer was consisted of small, rounded or oval granule cells. They were widely separated from each other. Some of them had vacuolated cytoplasm but few of them had deeply stained irregular shrunken nuclei (Figures 2B, 2H\&3E).

In sagittal cerebellar cortex stained sections (H \& E and toluidine blue) from offspring in subgroup VB, light microscopic examination showed that it consisted of 4 layers; external granular, molecular, Purkinje and internal granular layers(Figure 2C). The external granular layer was present as 1-2 rows (Figures 2C, 3C) as compared to subgroup IVB. The external granular cells were variable in size, rounded or oval, with deeply stained nuclei with prominent nucleoli (Figures 2C, 3C). Few granular cells were surrounded by vacuolated cytoplasm (Figures 2C and 2F). The thickness of the molecular layer was increased as compared to the molecular layer of subgroup IVB. The stellate and basket cells were nearly similar to the control subgroup. However, few of the stellate and basket cells had vacuolated cytoplasm (Figures 2C, 2F, 2I, 3C\&3F). Most of the Purkinje cells appeared nearly similar to the control group
(Figures 2I \&3F). Few Purkinje cells had irregular illdefined nuclei. Most of their axons arose from the bases and directed towards the internal granular layer and the dendrites toward the molecular layer (Figures 2I\&3F). The internal granular layer was consisted of many granule cells of and were separated by small acidophilic areas similar to the control. Few of the granule cells were surrounded by vacuolated cytoplasm (Figures 2I\&3F).

\section{Electron microscopy}

Electron microscopic examination of the cerebellar cortex of offspring in subgroups IB, IIB and IIIB revealed no obvious histological differences so their data were pooled together. Examination of ultrathin sections of the cerebellar cortex of these subgroups revealed that the molecular layer was composed of a complex network of neuronal cells and nerve fibers. The stellate cells of the molecular layer were rounded and had rounded euchromatic nuclei with demarcated nuclear envelopes containing many nuclear pores. The nuclei contained prominent nucleoli and small clumps of heterochromatin. The cytoplasm contained multiple cellular organelles; free ribosomes, rough endoplasmic reticulum, mitochondria and Golgi apparatus (Figure 4A).The basket cells of the molecular layer were oval and had large oval euchromatic nuclei with small clumps of heterochromatin. The nuclei were demarcated by nuclear envelope containing many nuclear pores. The cytoplasm contained free ribosomes, rough endoplasmic reticulum and mitochondria (Figure 4D). The neuropil of the molecular layer consisted of the dendrites and axons. The dendrites contained parallel microtubules and neurofilaments, free ribosomes and mitochondria. The axons contained numerous rounded vesicles of varying size (Figures 4A, 4D\&5A). The Purkinje cells had invaginated euchromatic nuclei with demarcated nuclear envelope. Their cytoplasm was very rich in cytoplasmic organelles; numerous rough endoplasmic reticulum, free ribosomes and mitochondria (Figure 6A). The granule cells were uniform oval in shape and had large oval heterochromatic nuclei which were surrounded by rim of cytoplasm. The rim of the cytoplasm contained free ribosomes and mitochondria (Figure 6D). The neuropil of the Purkinje cell layer and the internal granular layer was formed of dendrites and axons.

Electron microscopic examination of the cerebellar cortex of offspring in subgroup IVB showed that some stellate cells of the molecular layer were irregular in shape and had heterochromatic nuclei. Their nuclei had nuclear envelopes with many nuclear pores. Their cytoplasm appeared swollen. It contained free ribosomes, some dilated rough endoplasmic reticulum and mitochondria with destructed cristae (Figure 4B). Some basket cells of the molecular layer were irregular and had large oval heterochromatic nuclei with demarcated nuclear envelopes containing many nuclear pores. Their cytoplasm was swollen and contained multiple cytoplasmic organelles; free ribosomes, dilated rough endoplasmic reticulum and mitochondria with destructed cristae (Figure 4E). Some 
dendrites contained dilated rough endoplasmic reticulum, area of undifferentiated structures, mitochondria that appeared degenerated or had destructed cristae and free ribosomes. The axons contained vesicles of varying size (Figure 5B). Some Purkinje cells were irregular with dense heterochromatic irregular nuclei. The nuclei had irregular nuclear envelope with ill-defined nuclear pores. The cytoplasmic organelles could hardly be differentiated (Figure 6B). Few mitochondria appeared with destructed cristae, others appeared degenerated. The granule cells of external and internal granular layers were oval or rounded, with heterochromatic nuclei. Some granule cells were irregular, shrunken, and had shrunken, irregular nuclei with condensed clumps of heterochromatin (Figure 6E).

Electron microscopic examination of the cerebellar cortex of offspring in subgroup VB showed that the stellate cells of the molecular layer were nearly similar to the control, they were oval and had euchromatic nuclei with small clumps of heterochromatin. Their nuclei had prominent nucleoli and were enclosed by the nuclear envelopes which had apparent nuclear pores. Their cytoplasm contained free ribosomes, rough endoplasmic reticulum, mitochondria and Golgi apparatus (Figure 4C). The basket cells appeared nearly similar to the control, they were oval, and had large oval euchromatic nuclei with small clumps of heterochromatin. The nuclei were enclosed by the nuclear envelope. The cytoplasm contained free ribosomes, rough endoplasmic reticulum and mitochondria. However, few rough endoplasmic reticulum appeared slightly dilated, few mitochondria showed degeneration (Figure 4F). The dendrites contained multiple organelles; parallel microtubules and neurofilaments, rough endoplasmic reticulum, free ribosomes, mitochondria. However, few mitochondria appeared degenerated and few dendrites contained areas of undifferentiated structure. The axons contained vesicles of varying size (Figure 5C). The Purkinje cells appeared nearly similar to the control group, the nuclei appeared euchromatic and surround by nuclear envelop. The cytoplasm was rich in cytoplasmic organelles; free ribosomes, rough endoplasmic reticulum and mitochondria. However, few mitochondria appeared degenerated (Figure 6C). The granule cells of external and internal granular layers were uniform oval in shape and had large oval heterochromatic nuclei which were surrounded by rim of cytoplasm. The rim of the cytoplasm contained free ribosomes, few mitochondria that showed destructed cristae (Figure 6F).

\section{Morphometric results}

Statistical analysis of the mean thickness of the molecular layer in each of the B subgroups showed that the mean thickness of the molecular layer in IVB subgroup was significantly $(P<0.05)$ lower than the means in subgroups IB, IIB, IIIB and VB (Table 1, 2). The mean thickness of the molecular layer in subgroup VB was significantly $(P<0.05)$ higher than the means in subgroup IVB (Tables 1,2 ).

Statistical analysis of the mean number of the Purkinje cells in each of the B subgroups showed that the mean number of the Purkinje cell in IVB subgroup was significantly $(P<0.05)$ lower than the means in subgroups IB, IIB, IIIB and VB (Table 3, 4). The mean number of the Purkinje cell in subgroup VB was significantly $(P<0.05)$ higher than the means in subgroup IVB (Tables 3,4 ). 

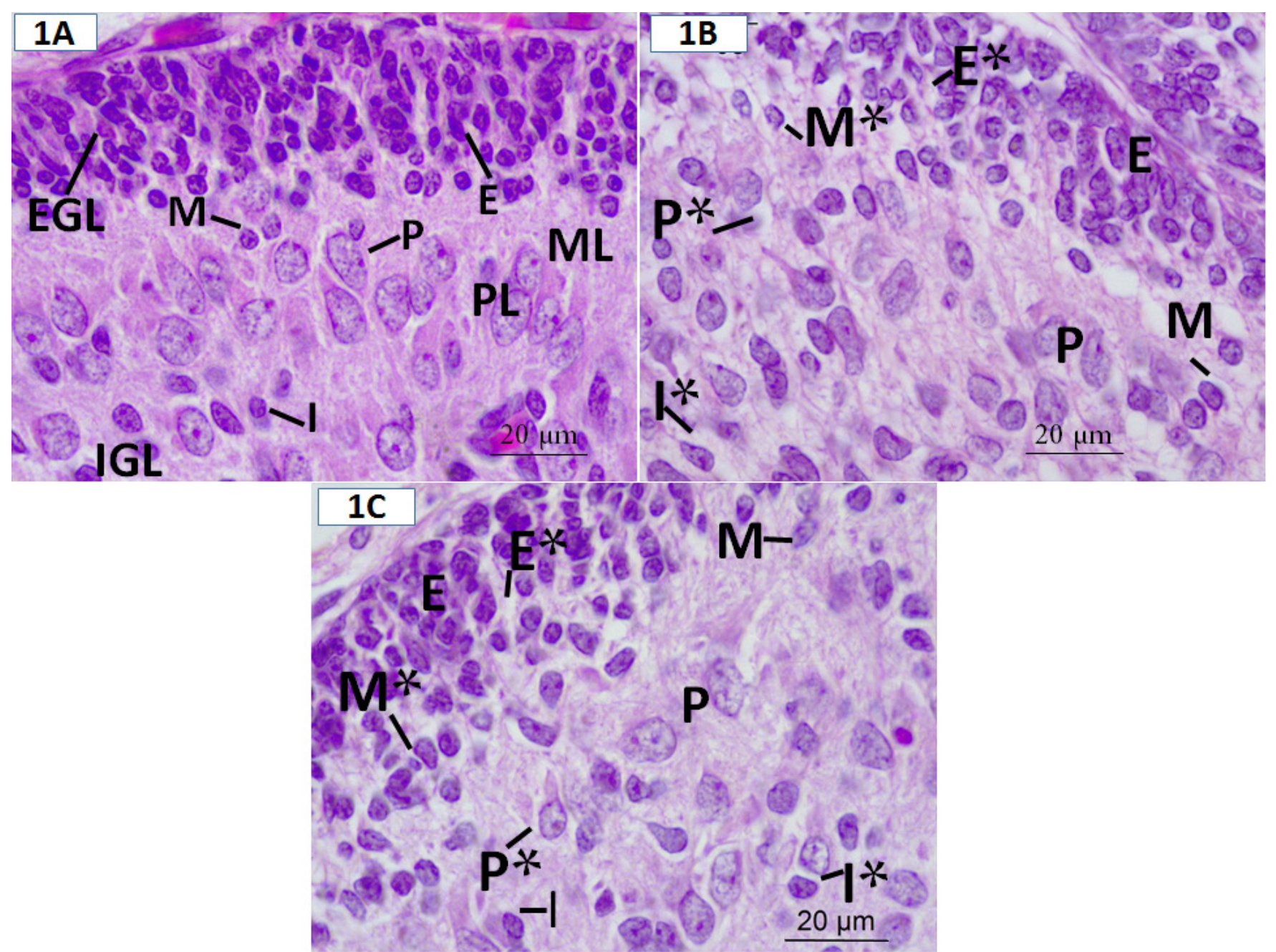

Fig. 1: Photomicrographs of sagittal sections of the rat offspring cerebellar cortex stained with H\&E and originally viewed at $\times 1000$ magnification.

Fig. 1A: Photomicrograph of a sagittal section of the rat offspring cerebellar cortex of IA, IIA and IIIA subgroups showing that the cerebellar cortex is consisted of the external granular layer (EGL), the molecular layer (ML), the Purkinje cell layer (PL) and the internal granular layer (IGL). The external granular layer is arranged in of 6-8 rows. The external granular cells (E) appear rounded and have deeply stained nuclei. The molecular cells (M) are rounded or oval with lightly stained nuclei. The Purkinje cells (P) are large oval with large rounded vesicular nuclei. The granule cells (I) of the internal granular layer appears rounded or oval with deeply stained nuclei.

Fig. 1B: Photomicrograph of a sagittal section of the rat offspring cerebellar cortex of IVA subgroup showing that the granule cells (E) of external granular layer is arranged in 4-6 rows. Most external granular cells are surrounded by vacuolated cytoplasm (E*).The molecular cells (M) appear few, rounded or oval with lightly stained nuclei, many of them are surrounded by vacuolated cytoplasm ( $\left.\mathrm{M}^{*}\right)$. The Purkinje cells $(\mathrm{P})$ are large oval with large rounded vesicular nuclei. Some of them are surrounded by vacuolated cytoplasm $\left(\mathrm{P}^{*}\right)$. The granule cells of the internal granular layer appear rounded with deeply stained nuclei. Some of them are surrounded by vacuolated cytoplasm (I*).

Fig.1C: Photomicrograph of a sagittal section of the rat offspring cerebellar cortex of VA subgroup showing that the granule cells (E) of external granular layer is arranged in 6-7 rows. Some external granular cells are surrounded by vacuolated cytoplasm ( $\left.\mathrm{E}^{*}\right)$. The molecular cells $(\mathrm{M})$ appear few, rounded or oval with lightly stained basophilic nuclei, few of them are surrounded by vacuolated cytoplasm ( $\left.\mathrm{M}^{*}\right)$. The Purkinje cells $(\mathrm{P})$ are large oval with large rounded vesicular nuclei. Few of them are surrounded by vacuolated area $\left(\mathrm{P}^{*}\right)$. The granule cells $(\mathrm{I})$ of the internal granular layer appear rounded or oval with deeply stained nuclei. Few of them are surrounded by vacuolated cytoplasm (I*). 


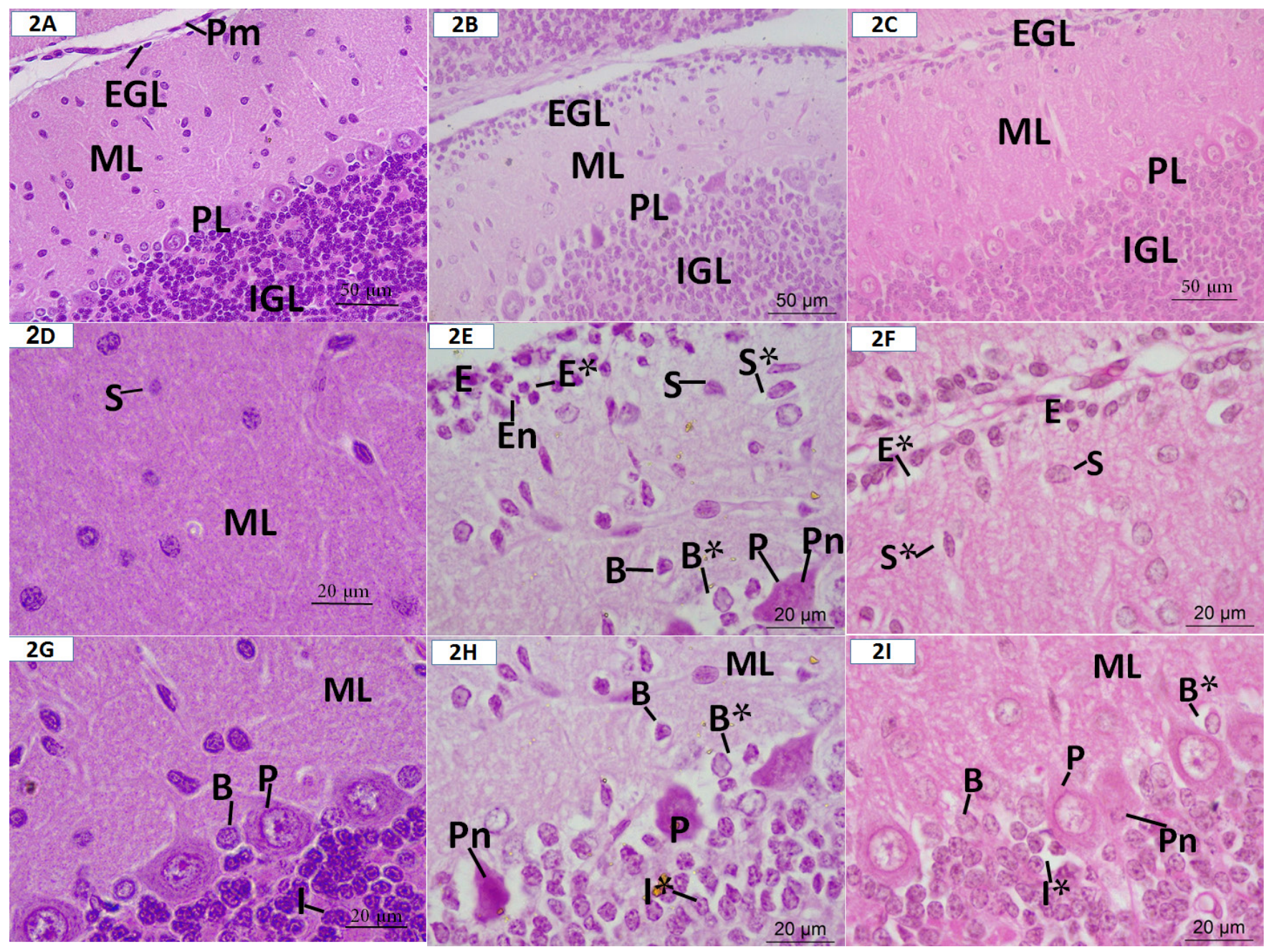

Fig. 2: Photomicrographs of sagittal sections of the rat offspring cerebellar cortex stained with H\&E. Figs. $(2 \mathrm{~A}, 2 \mathrm{~B}, 2 \mathrm{C})$ are originally viewed at $\times 400$ magnification and figs. $(2 \mathrm{D}, 2 \mathrm{E}, 2 \mathrm{~F}, 2 \mathrm{G}, 2 \mathrm{H}, 2 \mathrm{I})$ are viewed at $\times 1000$ magnification.

Fig.2A: Photomicrograph of a sagittal section of the rat offspring cerebellar cortex of IB, IIB, IIIB subgroups showing that the cerebellar cortex is consisted of 4 layers; External granular layer (EGL) beneath the pia matter (Pm), the molecular layer (ML), the Purkinje cell layer (PL) and the internal granular layer (IGL). The external granular layer is consisted of 1 rows of external granular cells in some areas or completely disappeared in other areas. The thickness of the molecular layer is increased as compared to the cortex of one day old offspring. The Purkinje cells are arranged in a single row. The internal granular layer is consisted of many granule cells which are aggregated in clusters and separated by small acidophilic areas.

Fig.2B: Photomicrograph of a sagittal section of the rat offspring cerebellar cortex of IVB subgroup showing that the cerebellar cortex is consisted of the external granular layer (EGL), the molecular layer (ML), the Purkinje cell layer (PL) and the internal granular layer (IGL). The external granular layer is arranged in 2-4 rows of external granular cells. The molecular layer is apparently decreased as compared to the control one. The Purkinje cells have deeply stained irregular nuclei.

Fig.2C: Photomicrograph of a sagittal section of the rat offspring cerebellar cortex of VB subgroup showing that the cerebellar cortex is consisted of the external granular layer (EGL), the molecular layer (ML), the Purkinje cell layer (PL) and the internal granular layer (IGL). The external granular layer is arranged in 1-2 rows of external granular cells. The thickness of the molecular layer is increased as compared to the molecular layer of subgroup IVB.

Fig. 2D: Photomicrograph of a sagittal section of the rat offspring cerebellar cortex of IB, IIB and IIIB subgroups showing the stellate cells (S) of the molecular layer (ML) appear oval or rounded, variable in size and have lightly stained nuclei with prominent nucleoli.

Fig.2E: Photomicrograph of a sagittal section of the rat offspring cerebellar cortex of IVB subgroup showing that the 2-4 rows of external granule cells (E) have vacuolated cytoplasm $\left(E^{*}\right)$ and some of them have deeply stained irregular shrunken nuclei (En). Some stellate (S) and basket cells (B) have vacuolated cytoplasm ( $\left.\mathrm{S}^{*}, \mathrm{~B}^{*}\right)$. The Purkinje cells $(\mathrm{P})$ appear oval with deeply stained ill-defined irregular nuclei $(\mathrm{Pn})$.

Fig.2F: Photomicrograph of a sagittal section of the rat offspring cerebellar cortex of VB subgroup showing that the external granular layer is consisted of 1-2 rows of external granular cells (E), few of them have vacuolated cytoplasm (E*). The stellate cells (S) appear oval and few of them have vacuolated cytoplasm $(\mathrm{S} *)$.

Fig. 2G: Photomicrograph of a sagittal section of the rat offspring cerebellar cortex of IB, IIB and IIIB subgroups showing the basket cells (B) of the molecular layer (ML) appear oval with lightly stained nuclei and prominent nucleoli and the Purkinje cells (P) appear flask in shape with large vesicular nuclei and prominent nucleoli. The granule cells (I) of the internal granular layer appear rounded or oval, with deeply stained nuclei and prominent nucleoli.

Fig.2H: Photomicrograph of a sagittal section of the rat offspring cerebellar cortex of IVB subgroup showing some of the basket cells (B) of molecular layer $(\mathrm{ML})$ have vacuolated cytoplasm (B*). Some of Purkinje cells $(\mathrm{P})$ have ill-defined nuclei (Pn). Some internal granular cells have vacuolated cytoplasm (I*).

Fig.2I: Photomicrograph of a sagittal section of the rat offspring cerebellar cortex of VB subgroup showing few of the basket cells (B) of molecular layer (ML) have vacuolated cytoplasm (B*). The Purkinje cells (P) appear oval, few of them have ill-defined outlines and ill-defined nuclei (Pn). Few internal granular cells have vacuolated cytoplasm (I*). 


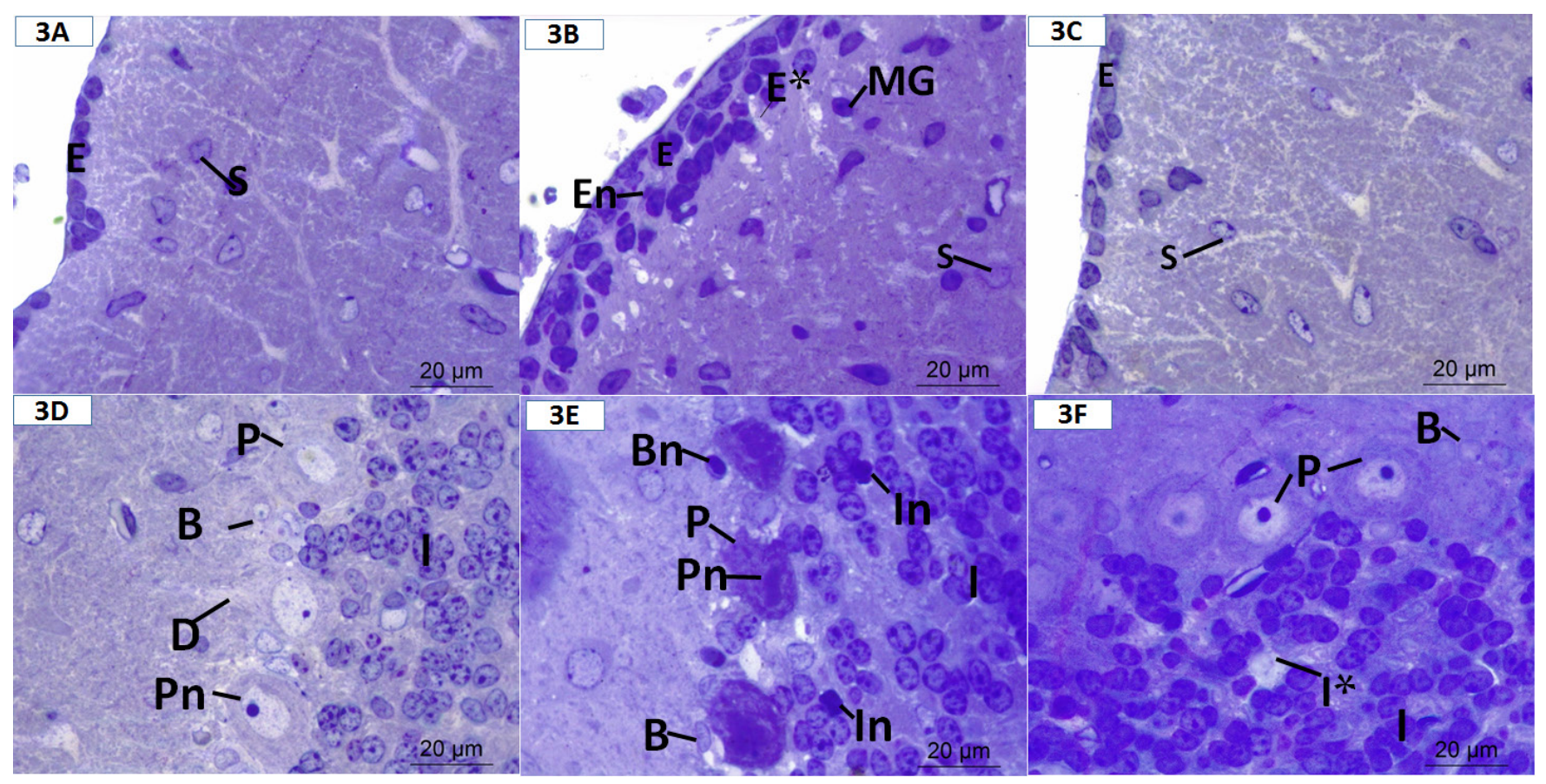

Fig. 3: Photomicrographs of sagittal sections of the rat offspring cerebellar cortex stained with Toluidine blue and originally viewed at $\times 1000$ magnification. Fig. 3A: Photomicrograph of a sagittal section of the rat offspring cerebellar cortex of IB, IIB and IIIB subgroups showing that external granular cells (E) is arranged in 1 row in some areas and disappeared in other areas. They appear rounded or oval with deeply stained nuclei and prominent nucleoli. The stellate cells (S) appear rounded or oval with lightly stained nuclei and prominent nucleoli.

Fig.3B: Photomicrograph of a sagittal section of the rat offspring cerebellar cortex of IVB subgroup showing that the external granular layer is consisted of 2-4 rows of granule cells (E) that have vacuolated cytoplasm (E*). Some of external granular cells have deeply stained irregular shrunken nuclei (En). The stellate cells (S) appear oval with lightly stained nuclei and prominent nucleoli. Migrating granular cells (MG) are noticed.

Fig.3C: Photomicrograph of a sagittal section of the rat offspring cerebellar cortex of VB subgroup showing the external granular layer is consisted of 1-2 rows of external granular cells (E). The stellate cells (S) appear oval and have lightly stained nuclei with prominent nucleoli.

Fig. 3D: Photomicrograph of a sagittal section of the rat offspring cerebellar cortex of IB, IIB and IIIB subgroups showing the basket cells (B) of the molecular layer appear oval with lightly stained nuclei and prominent nucleoli. The Purkinje cells (P) appear flask in shape with large vesicular nuclei (Pn). The granule cells (I) of the internal granular layer appear rounded or oval, with deeply stained nuclei and prominent nucleoli. The dendrites (D) of Purkinje cells are directed toward the molecular layer.

Fig.3E: Photomicrograph of a sagittal section of the rat offspring cerebellar cortex of IVB subgroup showing that the basket cells (B) of molecular layer appear oval or rounded, some of them have deeply stained nuclei (Bn). The Purkinje cells (P) appear oval, some of them have deeply stained irregular nuclei (Pn). Some internal granular cells (I) have deeply stained shrunken irregular nuclei (In).

Fig.3F: Photomicrograph of a sagittal section of the rat offspring cerebellar cortex of VB subgroup showing the basket cells (B) of molecular appear oval or rounded with lightly stained nuclei and prominent nucleoli. The Purkinje cells (P) appear flask in shape with large vesicular nuclei and prominent nucleoli. Few internal granular cells (I) have vacuolated cytoplasm (I*). 

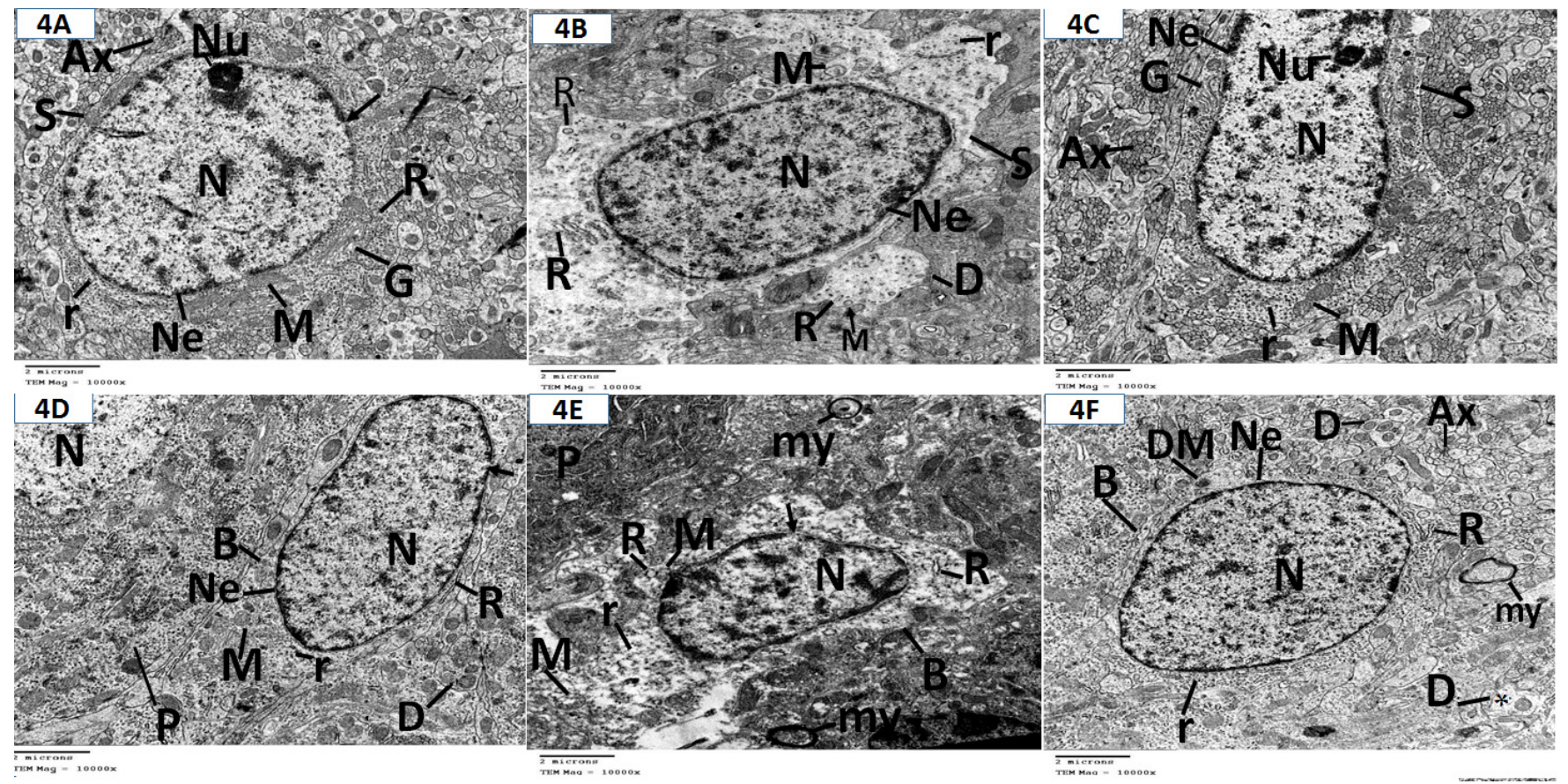

Fig. 4: Electron micrographs of the molecular layer originally viewed at $\times 10,000$ magnification.

Fig. 4A: Electron micrograph of the molecular layer of IB, IIB and IIIB subgroups showing the stellate cell (S) appear rounded has rounded euchromatic nucleus $(\mathrm{N})$ with prominent nucleolus $(\mathrm{Nu})$. The nucleus has nuclear envelope $(\mathrm{Ne})$ with apparent nuclear pores (arrow). The cytoplasm contains mitochondria $(\mathrm{M})$, rough endoplasmic reticulum(R), Golgi (G) and free ribosomes(r). Axons (Ax) are also noticed.

Fig.4B: Electron micrograph of the molecular layer of IVB subgroup showing the stellate cell(S) which is irregular in shape and has heterochromatic nucleus $(\mathrm{N})$ with nuclear envelope $(\mathrm{Ne})$. The cytoplasm is swollen and contains free ribosomes $(\mathrm{r})$, dilated rough endoplasmic reticulum $(\mathrm{R})$, mitochondria with destructed cristae (M). The dendrites (D) contain dilated rough endoplasmic reticulum(R) and mitochondria with destructed cristae (M).

Fig.4C: Electron micrograph of the molecular layer of VB subgroup showing the stellate cell (S) has oval euchromatic nucleus (N) with prominent nucleolus $(\mathrm{Nu})$ and nuclear envelop $(\mathrm{Ne})$. The cytoplasm contains mitochondria $(\mathrm{M})$, Golgi $(\mathrm{G})$ and free ribosomes(r). Axons $(\mathrm{Ax})$ are also noticed.

Fig. 4D: Electron micrograph of the molecular layer of IB, IIB and IIIB subgroups showing the basket cell (B) and part of Purkinje cell (P) with its nucleus $(\mathrm{N})$. The basket cell appears oval and has oval euchromatic nucleus $(\mathrm{N})$ with nuclear envelope $(\mathrm{Ne})$ that contains several nuclear pores (arrow). Its cytoplasm contains rough endoplasmic reticulum (R), free ribosomes (r), and mitochondria (M). Dendrites (D) are also noticed.

Fig.4E: Electron micrograph of the molecular layer of IVB subgroup showing the basket cell (B) which is irregular in shape and has heterochromatic nucleus $(\mathrm{N})$ with nuclear envelope ( $\mathrm{Ne}$ ) and apparent nuclear pores (arrow). Its cytoplasm is swollen and contains free ribosomes (r), dilated rough endoplasmic reticulum (R) and mitochondria with destructed cristae (M). Myelinated axons (my) and Purkinje cell (P) are noticed.

Fig.4F: Electron micrograph of the molecular layer of VB subgroup showing that the basket cell (B) has oval euchromatic nucleus (N) with nuclear envelope $(\mathrm{Ne})$. Its cytoplasm contains free ribosomes (r), mitochondria, few dilated rough endoplasmic reticulum (R) and degenerated mitochondria (DM). Some dendrites (D) with undifferentiated area (star), myelinated axons (my) and non myelinated axons (Ax) are also noticed. 

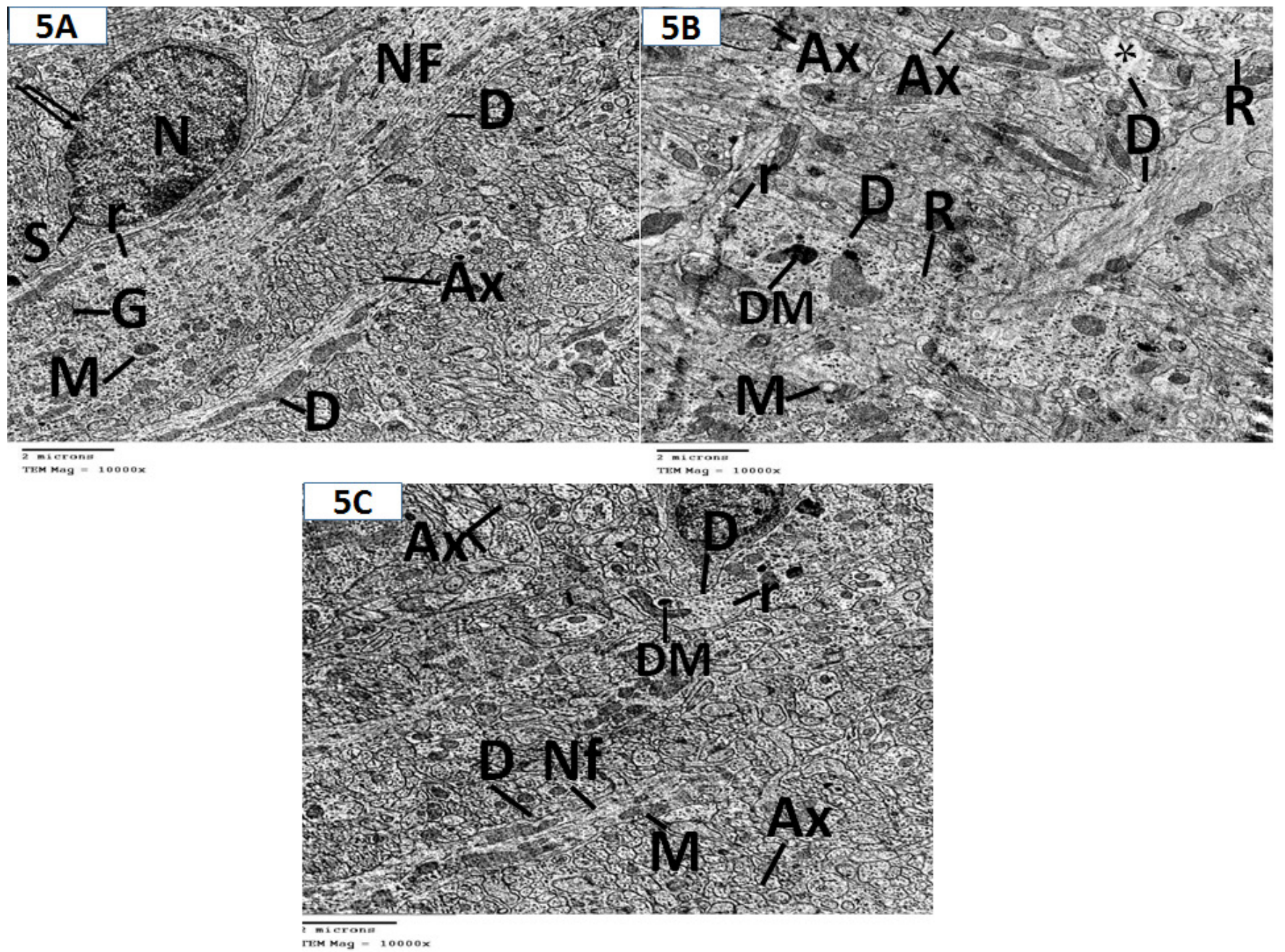

Fig. 5: Electron micrographs of the molecular layer originally viewed at $\times 10,000$ magnification

Fig. 5A: Electron micrograph of the molecular layer of IB, IIB and IIIB subgroups showing the dendrites (D) contain parallel microtubules and neurofilaments (Nf), rough endoplasmic reticulum (R), free ribosomes (r), Golgi (G), and mitochondria (M). Axons (Ax) contain vesicles of varying size and stellate cell(S) with invaginated ( 2 arrow) nucleus $(\mathrm{N})$ are noticed.

Fig.5B: Electron micrograph of the molecular layer of IVB subgroup showing profiles of dendrites and axons. Some dendrites appear swollen (D) and contain free ribosomes(r), area of undifferentiated structure (star), dilated rough endoplasmic reticulum (R) and mitochondria with destructed cristae (M) or degenerated (DM). The axons ( $\mathrm{Ax}$ ) have vesicles of varying size.

Fig.5C: Electron micrograph of the molecular layer of VB subgroup showing profiles of dendrites and axons. The dendrites (D) contain parallel microtubules and neurofilaments (Nf), free ribosomes (r) and mitochondria (M). Few mitochondria appear degenerated (DM). Axons (Ax) contain vesicles of varying size. 


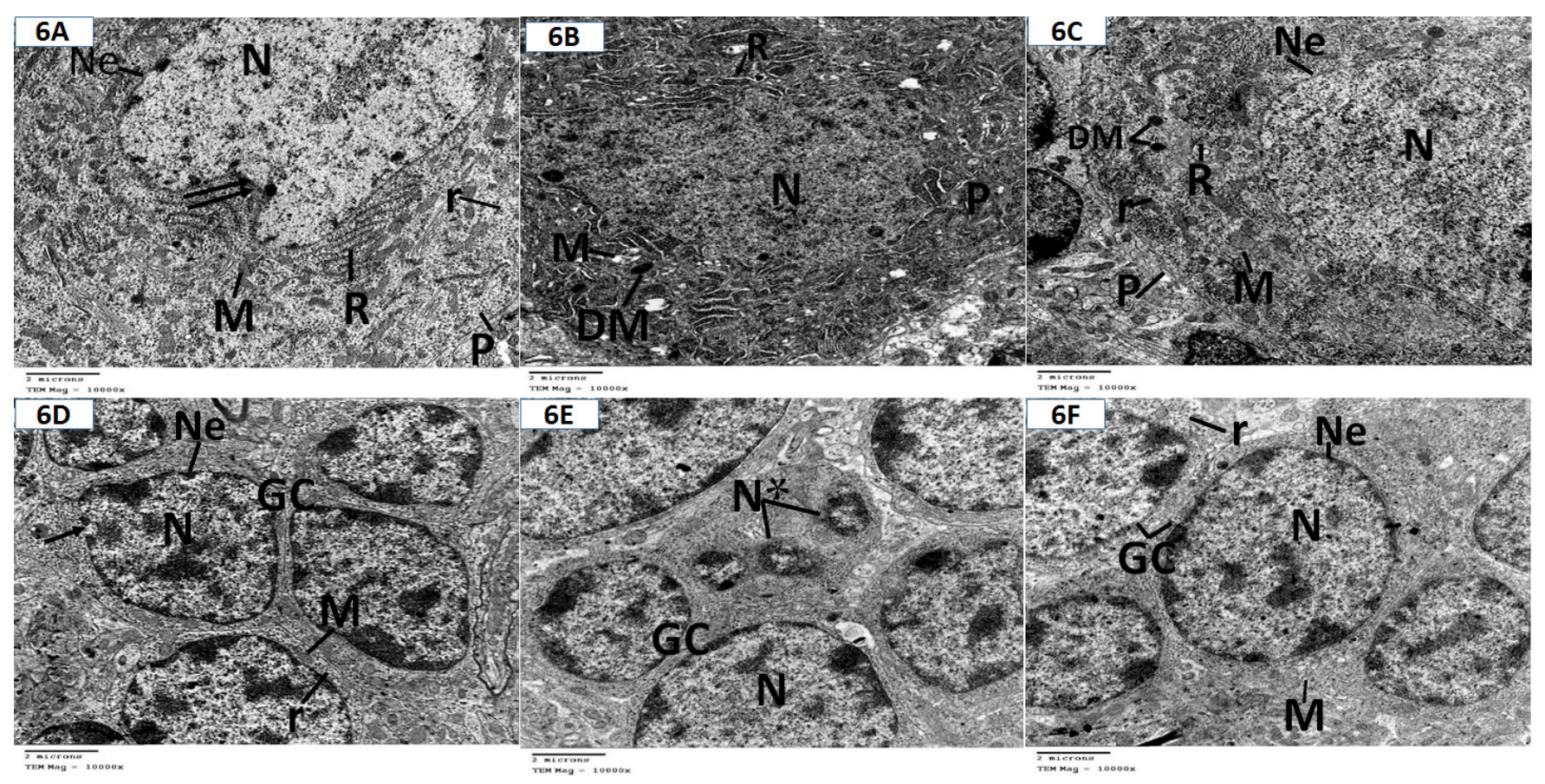

Fig.6: Electron micrographs of parts of the Purkinje cells $(6 \mathrm{~A}, 6 \mathrm{~B} \& 6 \mathrm{C})$ and internal granular cells $(6 \mathrm{D}, 6 \mathrm{E} \& 6 \mathrm{~F})$ originally viewed at $\times 10,000$ magnification. Fig.6A: Electron micrograph of part of the Purkinje cell of IB, IIB and IIIB subgroups showing that the Purkinje cell (P) has invaginated (2 arrows) euchromatic nucleus $(\mathrm{N})$ and well demarcated nuclear envelope $(\mathrm{Ne})$. The cytoplasm contains free ribosomes (r), rough endoplasmic reticulum $(\mathrm{R})$ and mitochondria $(\mathrm{M})$. Fig.6B: Electron micrograph of part of the Purkinje cell of IVB subgroup showing the Purkinje cell (P) has irregular heterochromatic nucleus (N) with illdefined nuclear envelope. Its cytoplasmic organelles could hardly be differentiated. Some mitochondria appear degenerated (DM) or with destructed cristae (M).Some rough endoplasmic reticulum appear dilated(R).

Fig.6C: Electron micrograph of part of the Purkinje cell of VB subgroup showing the Purkinje cell (P) has euchromatic nucleus $(\mathrm{N})$ with well demarcated nuclear envelope $(\mathrm{Ne})$. The cytoplasm contains free ribosomes (r), dilated rough endoplasmic reticulum $(\mathrm{R})$, and mitochondria $(\mathrm{M})$. Few mitochondria appear degenerated (DM).

Fig. 6D: Electron micrograph of the internal granular cells of IB, IIB and IIIB subgroups showing the granule cells (GC) are uniform oval in shape. They have heterochromatic oval nuclei $(\mathrm{N})$ with well demarcated nuclear envelope $(\mathrm{Ne})$ that contains nuclear pores (arrow). Their cytoplasm contains free ribosomes (r) and mitochondria $(\mathrm{M})$.

Fig. 6E: Electron micrograph of the internal granular cells of IVB subgroup showing some granule cells (GC) appear oval with oval heterochromatic nuclei $(\mathrm{N})$. Other granule cells appear shrunken with irregular shrunken heterochromatic nucleus $\left(\mathrm{N}^{*}\right)$ and ill-defined nuclear envelope.

Fig. 6F: Electron micrograph of the internal granular cells of VB subgroup showing that the granule cells (GC) have heterochromatic oval nuclei (N) with well demarcated nuclear envelope $(\mathrm{Ne})$ and the cytoplasm contains free ribosomes (r) and mitochondria $(\mathrm{M})$. 
Table 1: Mean height of molecular layer in treatment subgroups IB-VB

\begin{tabular}{|c|c|c|c|}
\hline \multirow{2}{*}{$\overbrace{\text { subgroups }}$} & \multirow{2}{*}{$\begin{array}{c}\text { Height of molecular layer } \\
\text { Mean } \pm \text { SD }\end{array}$} & \multicolumn{2}{|c|}{ One Way ANOVA } \\
\hline & & $F$ value & Pvalue \\
\hline IB & $187.8 \pm 12.92$ & & \\
\hline IIB & $187.9 \pm 12.69$ & & \\
\hline IIIB & $188.62 \pm 11.88$ & 103.3 & $<0.001$ \\
\hline IVB & $147.64 \pm 8.65$ & & \\
\hline VB & $178.18 \pm 14.1$ & & \\
\hline
\end{tabular}

Table 2: Tukey's Post hoc multiple comparisons to investigate differences between heights of molecular layer in individual subgroups.

\begin{tabular}{cccccccccc}
\hline IB vs IIB & IB vs IIIB & IB vs IVB & IB vs VB & IIB vs III B & IIB vs IV B & IIB vs V B & IIIB vs IVB & IIIB vs V B & IVB vs VB \\
\hline 0.999 & 0.997 & $<0.001$ & $<0.05$ & 0.999 & $<0.001$ & $<0.05$ & $<0.001$ & $<0.05$ & $<0.001$ \\
\hline
\end{tabular}

Table 3: Mean number of Purkinje cells in treatment subgroups IB-VB

\begin{tabular}{lccc}
\hline subgroups & Parameter & Number of Purkinje cells & One Way ANOVA \\
\cline { 2 - 4 } IB & Mean \pm SD & F value & \\
IIB & $41.98 \pm 2.12$ & \\
IIIB & $42.0 \pm 1.98$ & 45.72 & $<0.001$ \\
IVB & $41.84 \pm 1.92$ & \\
VB & $37.51 \pm 1.65$ & & \\
\hline
\end{tabular}

Table 4: Tukey's Post hoc multiple comparisons to investigate differences between number of Purkinje cells in individual subgroups.

\begin{tabular}{cccccccccc}
\hline IB vs IIB & IB vs IIIB & IB vs IVB & IB vs VB & IIB vs III B & IIB vs IV B & IIB vs V B & IIIB vs IVB & IIIB vs V B & IVB vs VB \\
\hline 0.999 & 0.999 & $<.001$ & 0.0483 & 0.999 & $<0.001$ & 0.0357 & $<0.001$ & 0.1108 & $<0.001$ \\
\hline
\end{tabular}

\section{DISCUSSION}

In the current study, treatment of pregnant albino rats with risperidone induced various signs of delayed development in the cerebellar cortex of their offspring. These signs were in the form of decreased the rows of external granular cells in IVA subgroup, increased the rows of external granular cells and significant decrease of the thickness of the molecular layer and the number of purkinje cells in IVB subgroups. These results were in line with Singh et al. ${ }^{\left[{ }^{[3]}\right.}$ who elucidated the effect of prenatal exposure to risperidone on developmental neurotoxicity in the neocortical region of fetal brain in young rat offspring. Their results indicated that there were reduction in the thickness of neocortical layers and altered cytoarchitecture of neocortical neurons.

In the present study, treatment of pregnant albino rats with risperidone also induced various signs of degeneration in the cerebellar cortex of their offspring. In IVA subgroup, the degenerative changes were displayed as areas of vacuolated cytoplasm in the cells of external granular, molecular, Purkinje and internal granular layers. In IVB subgroup, the degenerative changes were irregularity in the shape of cerebellar cells, cytoplasmic vacuoles, swollen mitochondria with destructed cristae, degenerated mitochondria, dilated rough endoplasmic reticulum and nuclear changes in the form of pyknosis. These changes were more apparent in the offspring of IVB subgroup than in offspring of IVA subgroup. These observations suggested that the effect of risperidone might be related to the duration of its administration. The results were supported by some authors ${ }^{[25]}$ who used longitudinal magnetic resonance imaging studies to compare changes in the volume of cortical gray matter over time between patients with schizophrenia and healthy control subjects. They found that patients with schizophrenia showed a significantly higher loss of total cortical gray matter volume. This was related to cumulative antipsychotic intake during the interval between scans in the whole study sample.

These results were also in agree with some authors ${ }^{[9]}$ who investigated the effect of prenatal exposure to risperidone on apoptotic neurodegeneration in neocortical region of fetal brain in young rat offspring. They found that there were apoptotic neurodegeneration in fetal brains, altered cytoarchitecture of neocortical neurons characterized by chromatin clumping, nuclear fragmentation and 
condensation, as well as irregular outlines of nuclei. Also, the results of the present study were in line with Singh and Singh ${ }^{[26]}$ who investigated the effect of prenatal exposure to risperidone on the fetal hippocampus, and their related functional changes in young rat offspring. Their results indicated that there was a significant decrease in the thickness of fetal hippocampus with disturbed cytoarchitectural pattern, and the volume of striatum and choroid plexus was also reduced.

In the present study, the degenerative changes induced by risperidone might be related to disturbance in the oxidant- antioxidant system. Such suggestion was in line with some authors ${ }^{[27]}$ who observed that risperidone administration was associated with a decrease in the total antioxidant status level and an increase in total oxidant status and oxidative stress index levels.

The degenerative changes that we observed in the cerebellar cortex of the offspring of treated rats might result from transplacental and translactational passage of risperidone. This suggestion was supported by some authors ${ }^{[28]}$ who reported that the placental passage rate for risperidone in pregnant female was $49 \%$. Also, some authors ${ }^{[29]}$ stated that risperidone secreted in breast milk is in low amounts.

In the present work, the combined administration of folic acid and risperidone led to an amelioration of the deleterious effects of risperidone on the cerebellar cortex of affected groups as confirmed by the improvement of the histopathological and morphometric analysis. These findings were in line with study ${ }^{[30]}$ whose authors evaluated the effects of exposure to electromagnetic fields emitted by mobile phones on the hippocampus and cerebellum of male Wistar albino rats and the neuroprotective effects of the antioxidants folic acid. Their results showed that folic acid can prevent the adverse effects of electromagnetic fields on the hippocampus and cerebellum, such as a decrease in the numbers of pyramidal neurons and neuronal degeneration. Also, Budni et al. ${ }^{[31]}$ evaluated the effect of folic acid administration against restraint stress-induced depressivelike behavior and cognitive deficit in mice. Their results indicated that folic acid displayed a specific antidepressant profile in the restraint stress paradigm.

On the other hand, the results of the present study were contrary to other studies that suggested that excessive dietary folic acid could be detrimental to neural development. Girotto et al. ${ }^{[32]}$ showed that supplementation of pregnant rats' diets with large doses of folic acid caused changes in brain synaptic transmission and higher susceptibility to seizures in their offspring. Also, some authors ${ }^{[33]}$ demonstrated that mice born to mothers fed a diet high in folic acid then fed after weaning on the same diet up to 6 months exhibited changes in gene expression in the cerebrum and also caused behavioral differences that included more ultrasonic vocalization, more anxiety, and hyperactivity.
The results of Barua et al. ${ }^{[33]}$ might be explained by the long duration of high dose folic acid intake.

In the current study, the neuroprotective effects of folic acid might be through reduction of oxidative stress. Such suggestion was supported by Budni et al. ${ }^{[31]}$ who attributed the specific antidepressant effect of folic acid in the restraint stress paradigm to its antioxidant role. Also, Sogut et al. ${ }^{[34]}$ aimed to investigate the prenatal alcohol exposure related neuroapoptosis on the cerebral cortex tissues of newborn rats and possible neuroprotective effects of betaine, folic acid. They observed that calpain, caspase- 3 activities, and cytochrome $\mathrm{c}$ levels were significantly increased in alcohol group. These increases were significantly reversed by folic acid treatments.

\section{CONCLUSION}

Treatment of the pregnant rats with risperidone induced delayed development and degenerative changes in the cerebellar cortex of their offspring. The co-administration of folic acid with risperidone led to an amelioration of these deleterious effects.

\section{RECOMMENDATIONS}

For pregnant and lactating women treated with risperidone, co-supplementation with folic acid is advisable.

\section{CONFLICTS OF INTEREST}

There are no conflicts of interest

\section{FUNDING DETAILS}

This research did not receive any specific grant from funding agencies in the public, commercial, or not-forprofit sectors

\section{REFERENCES}

1. Schatzberg A F, Nemeroff C B. Textbook of Psychopharmacology. $5^{\text {th }}$ ed, Pbl. American psychiatric association publishing, 2017, pp. 705-730.

2. Sadock B J, Sadock V A. Concise textbook of clinical psychiatry.3rd ed. Pbl. Lippincott William and Wilkins, Philadelphia, USA, 2008, PP.543.

3. Bishop J R, Pavuluri M N. Review of risperidone for the treatment of pediatric and adolescent bipolar disorder and schizophrenia. Neuropsychiatric Disease Treatment 2008; 4(1):55-68.

4. Kemp DE, Canan F, Goldstein BI, McIntyre RS Long-acting risperidone: a review of its role in the treatment of bipolar disorder. Advances in Therapy 2009; 26(6):588-599.

5. Corbeil P, Rodrigue J, Simoneau M, Cohen $\mathrm{H}$, Pourcher E. Influence of risperidone on balance control in young healthy individuals. Psychopharmacology (Berl) 2012; 222(1):59-69. 
6. Kane JM, Correll CU. Past and present progress in the pharmacologic treatment of schizophrenia. J Clin Psychiatry, 2010; 71:1115-1124.

7. Sadowski A, Todorow M, Brojeni P Y, Koren G, Nulman I. Pregnancy outcomes following maternal exposure to second-generation antipsychotics given with other psychotropic drugs: a cohort study. BMJ Open, 2013; 3: 1-10.

8. Paschetta E, Rosso G, Maina G. Atypical antipsychotics, maternal and child outcomes: a critical review. OA Women's Health, 2014; 2 (1): $1-9$.

9. Singh K P, Singh M K, Singh M. Effects of prenatal exposure to antipsychotic risperidone on developmental neurotoxicity, apoptotic neurodegeneration and neurobehavioral sequelae in rat offspring. Int. J. Devl Neuroscience, 2016; 52:13-23.

10. Brunton LL, Blumenthal D K, Buxton I L, Parker KL.The Goodman \& Gilman manual of pharmacology and therapeutics. $11^{\text {th }}$ ed., Pbl. McGraw-Hill Companies. United States, 2008: pp.944-946.

11. Pietrzik K, Bailey L, Shane B. Folic acid and L-5methyltetrahydrofolate: comparison of clinical pharmacokinetics and pharmacodynamics. Clin Pharmacokinet. 2010; 48:535-548.

12. Crider KS, Yang T P, Berry R J, Bailey LB. Folate and DNA methylation: a review of molecular mechanisms and the evidence for folate's role. Adv. Nutr. 2012; 3: 21.

13. Barar FSK. Textbook of pharmacology for pharmacy students. $1^{\text {st }}$ ed. Pbl. S. Chand and Company Ltd, NewDehi. 2013, pp.274.

14. Wolff T, Witkop CT, Miller T. Syed S. Folic acid supplementation for the prevention of neural tube defects: an update of the evidence for the US preventive services task force. Ann Intern Med. 2009; 150:632-639

15. Blencowe H, Cousens S, Modell B, Lawn J. Folic acid to reduce neonatal mortality from neural tube disorders. Int J Epidemiol. 2010; 39:i110-i121

16. Marder S R, Glynn S M, Wirshing W C, Wirshing D A, Ross D, Widmark C, Mintz J, Liberman R P, Blair K E. Maintenance treatment of schizophrenia with risperidon or haloperidol : 2-year out $\neg$ come. Am J Psychiatry, 2003; 160(8): 1405-1412.

17. Mirabzadeh A, Kimiaghalam P, Fadai F, Samiei M, Daneshmand R. The Therapeutic Effectiveness of Risperidone on Negative Symptoms of Schizophrenia in Comparison with Haloperidol: A Randomized Clinical Trial. Basic and Clinical Neuroscience, 2014; 5(3): 212-217.
18. Marder S R, Meibach R C. Risperidone in the treat $\neg$ ment of schizophrenia, Am J Psychiatry1994; 151(6): 825-835.

19. Paget G C, Barnes J M. Toxicity in evaluation of the drug activities. Pharmacometric. Vol. I edited by: Laurence, D. R. and Bacharach, A. L. $1^{\text {st }}$ ed. Pbl. Academic Press. London, New York, 1964, pp. 1-13.

20. Briggs G G, Freeman R K, Yaffe S J. Drug in pregnancy and lactation. $9^{\text {th }}$ ed. $\mathrm{Pbl}$ Lippincott Wiliams \& Wilkins, Philadelphia 2011: pp. 1283-1284

21. Neves E G, Ramos-Perez F M, Freitas D Q, Boscolo F N, Almeida S M. Radioprotective effect of sodium selenite on developing teeth. Brazilian Dental Journal, 2013; 24: 375-379.

22. Suvarna S, Layton C, Bancroft J. Bancroft's theory and practice of histological techniques. $8^{\text {th }}$ ed. Pbl. Amsterdam, Elsevier, 2018, pp.40-64.

23. Bancroft J D, Gamble M. Theory and practice of histological techniques. $5^{\text {th }}$ ed. Pbl. Churchill Livingston, Edinburg, 2002, pp. 593-620.

24. Mould RF. Introductory medical statistics. $3^{\text {rd }}$ ed., Pbl. Institute of physics publishing, Dirac house, Bristol, 1998: pp.196-203.

25. Vita A, Peri L, Deste G, Barlati S, Sacchetti E. The Effect of Antipsychotic Treatment on Cortical Gray Matter Changes in Schizophrenia: Does the Class Matter? A Meta-analysis and Metaregression of Longitudinal Magnetic Resonance Imaging Studies. Biological Psychiatry, 2015; 78(6): 403-412.

26. Singh K P, Singh M K. In utero exposure to atypical antipsychotic drug, risperidone: Effects on fetal neurotoxicity in hippocampal region and cognitive impairment in rat offspring. Progress in NeuroPsychopharmacology and Biological Psychiatry, 2017; 75:35-44.

27. Bilgiç S, Korkmaz DT, Azirak S, Güvenç A N, Kocaman N, Özer M K. Risperidone-Induced Renal Damage and Metabolic Side Effects: The Protective Effect of Resveratrol. Oxidative Medicine and Cellular Longevity; 2017, Article ID 8709521, 10 pages.

28. Newport D J, Hyman J. Management of Bibolar Disorders during Pregnancy and Lactation. In: Yildi A, Ruiz P, and Nemeroff C. The Bipolar book: History, neurobiology, and treatment" $1^{\text {st }}$ ed., Pbl. oxoford university press, USA.2015: pp. 530-536.

29. Odhejo Y I, Jafri A, Mekala HM, Hassan M, Mahmood K A, Dar S K, Ahmed R. Safety and Efficacy of Antipsychotics in Pregnancy and Lactation. J Alcohol Drug Depend. 2017; 5(3): 267 
30. Kivrak E G, Altunkaynak B Z, Alkan I, Yurt K K, Kocaman A, Onger M E. Effects of 900-MHz radiation on the hippocampus and cerebellum of adult rats and attenuation of such effects by folic acid and Boswellia sacra. Journal of Microscopy and Ultrastructure2017; 5:216-224.

31. Budni J, Zomkowski AD, Engel D, Santos D B, Santos A A, Moretti M, Valvassori S S, Ornell F, Quevedo J, Farina M, Rodrigues, A L S. Folic acid prevents depressive-like behavior and hippocampal antioxidant imbalance induced by restraint stress in mice. Experimental Neurology 2013; 240: 112-121.

32. Girotto F, Scott L, Avchalumov Y, Harris J, Iannattone $\mathrm{S}$, Drummond-Main $\mathrm{C}$, Tobias $\mathrm{R}$,
Bello-Espinosa L, Rho JM, Davidsen J. High dose folic acid supplementation of rats alters synaptic transmission and seizure susceptibility in offspring. Sci. Rep. 2013; 3, 1465.

33. Barua B, Chadman K K, Kuizon S, Buenaventura D, Stapley NW, Ruocco F, Begum U, Guariglia SR, Brown WT, Juniad MA.Increasing maternal or post-weaning folic acid alters gene expression and moderately changes behavior in the offspring. PLoS ONE, 2014, 9: e101674.

34. Sogut I, Uysal O, Oglakci A, Yucel F, Kartkay K, Kanbak G. Prenatal alcohol-induced neuroapoptosis in rat brain cerebral cortex: protective effect of folic acid and betaine. Child's Nervous System 2017; 33(3):407-417. 


\section{الملخص العربى}

التغيرات النسيجية للريسبيريدون وحمض الفوليك على قثرة مخيخ نسل الجرذان البيضاء صفاء مسعود حنفي

\section{قسم التشريح والأجنة ـ كلية الطب( بنات) - جامعة الأزهر}

خلقية البحث: الريسبيريدون هو أحد مضادات الذهان من الجيل الثناني وحمض الفوليك هو أحد مركبات فيتامين ب. الهدف من البحث: تقييم آثار الريسبيريدون على نمو قشرة مخيخ نسل الجرذان البيضاء ، وتقييم إمكانات الحماية بحمض الفوليك أجري هذا البحث على 60 من الجرذان البيضاء الحوامل و180 من نسلهن. وقد تم تقسيم الجرذان بالتساوي إلى خمس مجمو عات رئيسية I6II،III،IV،V. ثم قسمت كل مجمو عة رئيسية الى مجمو عتين فر عيتين A و B وقد تم إعطاء الجرذان فى المجموعات الفرعيةIIA ،IIA،IIIA،IVA،VA الجرعات التالية على التو الي أثناء فترة ، الحمل: المجموعة الاولى 1ملي من الماء المقطر، المجموعة الثانية 0.58ملي من الماء المقطر المجموعة الثالثة: 0.58 ملي من الماء المقطر يحتوي على 0.072 ملجم من حمض الفوليك، المجموعة الر ابعة: 1ملي من الماء المقطر يحتوي على 0.108 ملجم ريسبيريدون، المجمو عة الخامسة: 1مل من الماء المقطر يحتوي على 0.108 ملجم الريسبيريدون بالاضافة الى 0.58 مل من الماء المقطر يحتوي على 0.072 ملجم من حمض الفوليك (VA) ) ـ تم إعطاء كل الجرذان فى المجموعات الفرعية IB ، نقس الجرعات التي أعطيت للمجمو عات الفر عية A أثناء فترة الحمل ولمدة واحد و عشرين يوما بعد الو لادة.

وقد تم الفحص المجهري الضوئي للمخيخ لنسل جميع المجموعات ـ كما نم إستخدام المخيخ للنسل فى عمر 21 يوم للفحص المجهري الإلكترونى و الدر اسة المورفومثرية.

النتائج: أحدث عقار الريسبيريدون علامات مختلفة للتأخر في نمو قشرة المخيخ ، كما تسبب في تغير ات انتكاسية في الخلايا المخيخية و الألياف العصبية على شكل فجوات سيتوبلازمية ، وتوسع الثبكة الإندوبلازمية الخشنة، و إنتفاخ المينوكوندريا ونخر ها ، وتدمير الكريستيا ، وتغيرات نووية. وتبين أن إعطاء حمض الفوليك أدى إلى تقليل الاثار السلبية للريسبيريدون على المخيخ. الإستتتاج: علاج الامهات الحوامل بعقار الريسبيريدون قد يتسبب في تغيرات انتاكسية وتأخير في نمو قنرة المخيخ للنسل. وللحد من هذه التغير ات التنكسية ، يفضل إضافة حمض الفوليك للعلاج. 